\title{
The Yields and Composition of Five Grasses Growing in the Humid Mountains of Puerto Rico, as Affected by Nitrogen Fertilization, Season, and Harvest Procedures ${ }^{1}$
}

\author{
Ruben Caro-Costas, José Vicente-Chandler, and Jacinto Figarella ${ }^{2}$
}

\section{INTRODUCTION}

Napier grass (Pennisetum purpureum), Guinea grass (Panicum maximum), Para grass (Panicum purpurascens), Pangola grass (Digitaria decumbens), and molasses grass (Melinis minutiflora), are among the most widely used forages of the humid Tropics. However, little is known of their relative productivity under different conditions as affected by fertilization, season of the year, and harvest procedure.

In Puerto Rico, Rodriguez (4) ( $^{3}$ found that applications of 200 pounds of nitrogen per acre yearly about doubled yields of Napier, Guinea, and Para grasses in the humid coastal area. Under similar conditions, Vicente, Silva, and Figarella (8) found that Napier, Guinea, and Para grasses responded in yield to nitrogen applications up to 800 pounds per acre yearly. Protein content and yields of the grasses increased sharply with nitrogen rates up to 1,600 pounds per acre yearly. About half of the fertilizer nitrogen was recovered in the forage at all rates up to 800 pounds per acre yearly, but pounds of dry matter produced per pound of nitrogen decreased beyond the 400-pound level. Phosphorus content of the forage decreased, lignin content increased, while the calcium, potassium, and magnesium contents were not consistently affected by increasing nitrogen rates. There were marked seasonal variations in yield. Rivera-Brenes $(3)$ found that Napier produced more green forage than Guinea or Para grasses in this area.

Vicente and Figarella ( 7 ) found that the application of 100 pounds of nitrogen per acre to unirrigated Guinea grass growing in the semiarid South coast increased yields by about one-third. Vicente, et al. (6) reported that applications of 300 pounds of nitrogen per acre yearly more than doubled yields of Guinea grass growing with irrigation in this region. Under similar conditions, Little, Vicente, and Abruña (2) found that yields of irrigated

1 This report covers work carried out cooperatively between the Soil and Water Conservation Research Division, Agricultural Research Service, USDA, and the Agricultural Experiment Station of the University of Puerto Rico.

2 Agronomist (cooperative between the above agencies), Project Supervisor, and Soil Scientist, Soil and Water Conservation Research Division, Agricultural Research Service, USDA, respectively, stationed at the Agricultural Experiment Station, University of Puerto Rico, Río Piedras, P. R.

${ }^{3}$ Italic numbers in parentheses refer to Literature Cited, pp. 119-20. 
Napier, and Guinea grasses increased with nitrogen rates up to 800 pounds per acre yearly, while Pangola grass responded little to applications of nitrogen in excess of 200 pounds. Protein content of the forage increased with nitrogen rates up to 1,600 pounds per acre yearly. Highest yields of dry matter were produced by Napier, followed by Guinea and Pangola grasses, in that order.

The experiment herein reported was carried out to determine the productivity of Napier, Guinea, Para, Pangola, and molasses grasses, as affected by nitrogen fertilization and season of the year, with both cutting and simulated grazing management under conditions typical of the steep humid mountains of Puerto Rico.

\section{MATERIALS AND METHODS}

The experiment was carried out at Orocovis, P.R., which has a mean annual temperature of about $75^{\circ} \mathrm{F}$., and a seasonal variation of less than $10^{\circ} \mathrm{F}$. Annual rainfall was 76 and 91.8 inches, respectively, for the 2 years of experimentation. The experiment was carried out on Catalina clay on a 30-percent slope. The surface 6 inches contained 4.5 percent of organic matter; it had a pH of 5.3, 16.5 m.e. of exchange capacity, and 10.4 m.e. of exchangeable bases per $100 \mathrm{gm}$. of soil, a volume weight of 0.98 with 11

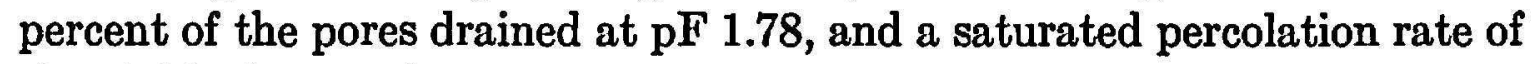
about 6 inches per hour.

\section{TREATMENTS}

Grasses used: Napier, Guinea, Pangola, molasses, and Pará with some Carib grass (Eriochloa polystàchya).

Nitrogen rates: $0,200,400$, and 800 pounds $N$ per acre yearly as ammonium sulfate in 6 or 9 equal applications, depending on frequency of harvest.

Harvest procedure: 1 , Cut every 60 days; 2 , simulated grazing every 40 days.

\section{METHODS}

Plots with cutting management were harvested every 60 days by cutting the grasses close to the ground. Simulated grazing was obtained by a combination of cutting and plucking once every 40 days, in an attempt to produce a condition comparable to that on companion plots intermittently grazed by livestock.

All combinations of treatments were tested using a split-plot design with harvest procedure as the main plots, grasses as the subplots, and nitrogen rates as the sub-subplots. The latter were $1 / 200$ of an acre in size, surrounded by ditches to prevent fertilizer from washing into adjoining plots. All treatments were replicated four times. 
The upper 6 inches of soil in all plots was limed to a $\mathrm{pH}$ of about 6.5 and relimed annually to this level. Blanket additions of phosphorus and potassium were made at the rate of 200 pounds of $\mathrm{P}_{2} \mathrm{O}_{5}$ from 20-percent superphosphate per acre in one annual application, and 400 pounds of $\mathrm{K}_{2} \mathrm{O}$ from $\mathrm{KCl}$ per acre yearly in six or nine equal applications, depending on frequency of harvest.

The forage from all plots at every harvest was weighed and analyzed for dry matter and total nitrogen. The crude protein was calculated using the factor $6.25 \times \mathrm{N}$. Samples from all cuttings of the second year were composited by plots and analyzed for calcium, phosphorus, potassium, magnesium, lignin, and "digestible laboratory nutrients", using the method of Thurman and Wehunt (5). Residual yields were taken over a 60-day period following termination of the experiment.

\section{RESULTS}

\section{YIELDS OF FORAGE}

The grasses gave about the same response to nitrogen fertilization in both years. The check plots were lower the second year, however, showing that the soil nitrogen had been depleted. Relative productivity of the grasses and effects of fertilization, harvesting procedure, and season were very similar during both years.

The data in table 1 show that molasses grass yielded much less than the others with both systems of harvesting when nitrogen was applied. With cutting management, Napier, Guinea, Pangola, and Para grasses yielded about the same at all nitrogen levels, except at the 800-pound rate, at which Napier produced about 20 percent more forage than the others. At the 400 pound nitrogen rate all these grasses yielded about 24,000 pounds of dry matter per acre yearly. With simulated grazing management, however, Guinea outyielded all the grasses at all nitrogen levels. Pangola, Napier, and Para grasses produced similar yields at all nitrogen levels.

These data and figure 1 show that all grasses, except molasses, responded in yield to nitrogen applications of up to 800 pounds per acre yearly, with both cutting and simulated grazing management. However, except with Napier harvested by cutting, and Guinea harvested by grazing, increases in yield fell off sharply beyond the 400-pound level. Yields of these four grasses were doubled or more by the application of 400 pounds of nitrogen per acre yearly. Molasses grass, on the other hand, gave only a moderate response to the application of 200 pounds of nitrogen, and was little affected by heavier applications.

All grasses yielded less with simulated grazing than with cutting management. With 400 pounds of nitrogen, yields of Para, Napier, and Pangola grasses were lowered 35,40 , and 31 percent, respectively, by simulated 
grazing, but those of Guinea and molasses grasses dropped only 16 and 20 percent, respectively. These decreases in yield were caused by the shorter harvest interval ( 8 ) as well as by the higher cutting in the grazed plots as discussed later.

TABLE 1.-The effect of nitrogen fertilization and 2 methods of harvesting on yields and protein contents of 5 tropical grasses, and on the efficiency of nitrogen utilization over a 2-year period

\begin{tabular}{|c|c|c|c|c|c|c|c|c|}
\hline \multirow[b]{2}{*}{$\begin{array}{l}\text { Grass and nitrogen } \\
\text { (pounds) per acre yearly }\end{array}$} & \multicolumn{4}{|c|}{$\begin{array}{l}\text { Grasses barvested by cutting } \\
\text { every } 60 \text { days }\end{array}$} & \multicolumn{4}{|c|}{$\begin{array}{l}\text { Grasses harvested by simulated } \\
\text { grazing every } 40 \text { days }\end{array}$} \\
\hline & $\left|\begin{array}{c}\text { Dry forage } \\
\text { per acre } \\
\text { yearly }\end{array}\right|$ & Protein & 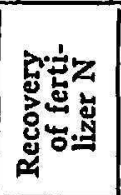 & 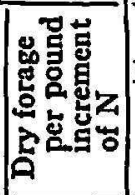 & $\begin{array}{c}\text { Dry forage } \\
\text { per acre } \\
\text { yearly }\end{array}$ & Protein & 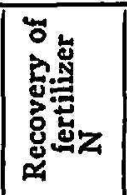 & 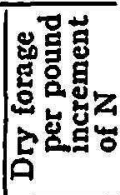 \\
\hline & $L b$. & $\begin{array}{l}\text { Per- } \\
\text { cent }\end{array}$ & Percent & $L b$. & $L b$. & Percent & Percent & Lb. \\
\hline \multicolumn{9}{|l|}{ Para grass } \\
\hline 0 & 8,742 & 6.4 & - & - & 6,693 & 8.2 & - & - \\
\hline 200 & 19,638 & 6.6 & 58.6 & 54.5 & 12,179 & 8.8 & 42.0 & 27.4 \\
\hline 400 & 24,025 & 8.0 & 55.0 & 21.9 & 15,694 & 10.0 & 41.0 & 17.6 \\
\hline 800 & 26,054 & 9.9 & 40.3 & 5.1 & 16,479 & 12.9 & 31.5 & 1.9 \\
\hline \multicolumn{9}{|l|}{ Guinea grass } \\
\hline 0 & 9,675 & 7.7 & 一 & - & 8,821 & 8.7 & - & - \\
\hline 200 & 19,645 & 7.6 & 60.2 & 49.9 & 15,176 & 8.8 & 45.6 & 31.8 \\
\hline 400 & 23,002 & 7.8 & 42.3 & 16.8 & 19,330 & 9.4 & 42.0 & 20.8 \\
\hline 800 & 28,180 & 10.0 & 41.5 & 12.9 & 26,696 & 11.4 & 45.3 & 18.4 \\
\hline \multicolumn{9}{|l|}{ Napier grass } \\
\hline 0 & 13,308 & 7.4 & - & - & 7,579 & 10.5 & - & - \\
\hline 200 & 21,395 & 6.9 & 39.9 & 40.4 & 11,591 & 10.6 & 35.2 & 20.1 \\
\hline 400 & 25,214 & 7.5 & 36.3 & 19.1 & 14,953 & 11.6 & 37.4 & 16.8 \\
\hline 800 & 33,284 & 8.7 & 38.5 & 20.2 & 19,415 & 12.8 & 33.7 & 11.2 \\
\hline \multicolumn{9}{|l|}{ Pangola grass } \\
\hline 0 & 8,614 & 6.4 & - & - & 6,981 & 7.0 & - & - \\
\hline 200 & 18,106 & 6.9 & 55.8 & 47.3 & 11,287 & 8.7 & 40.5 & 21.5 \\
\hline 400 & 23,707 & 7.9 & 53.0 & 28.0 & 16,332 & 10.3 & 47.9 & 25.2 \\
\hline 800 & 26,686 & 10.9 & 47.1 & 7.4 & 18,362 & 12.0 & 34.4 & 5.1 \\
\hline \multicolumn{9}{|l|}{ Molasses grass } \\
\hline 0 & 9,275 & 7.3 & - & 一 & 6,479 & 7.9 & - & - \\
\hline 200 & 13,271 & 8.1 & 32.0 & 20.0 & 8,880 & 8.4 & 18.7 & 12.0 \\
\hline 400 & 13,246 & 9.8 & 25.0 & - & 10,647 & 10.1 & 22.6 & 8.8 \\
\hline 800 & 11,937 & 11.2 & 13.2 & - & 8,863 & 11.8 & 10.8 & - \\
\hline
\end{tabular}

Figure 2 shows that season of the year had a marked and very similar influence on yields of all grasses with lowest productivity during the winter months of December through March. Napier grass produced more forage than the others during the last months of both years.

Table 2 shows that seasonal variations in yield generally increased 
sharply with nitrogen rates up to 400 pounds per acre yearly. However, the variation was not further accentuated by raising rates to 800 pounds of nitrogen.

Figures 3 and 4 show that season of the year also strongly affected the response of the grasses to nitrogen fertilization with both simulated grazing and cutting management. Rate of yield increases with nitrogen fertilization were much lower during the winter months. Molasses grass generally re-

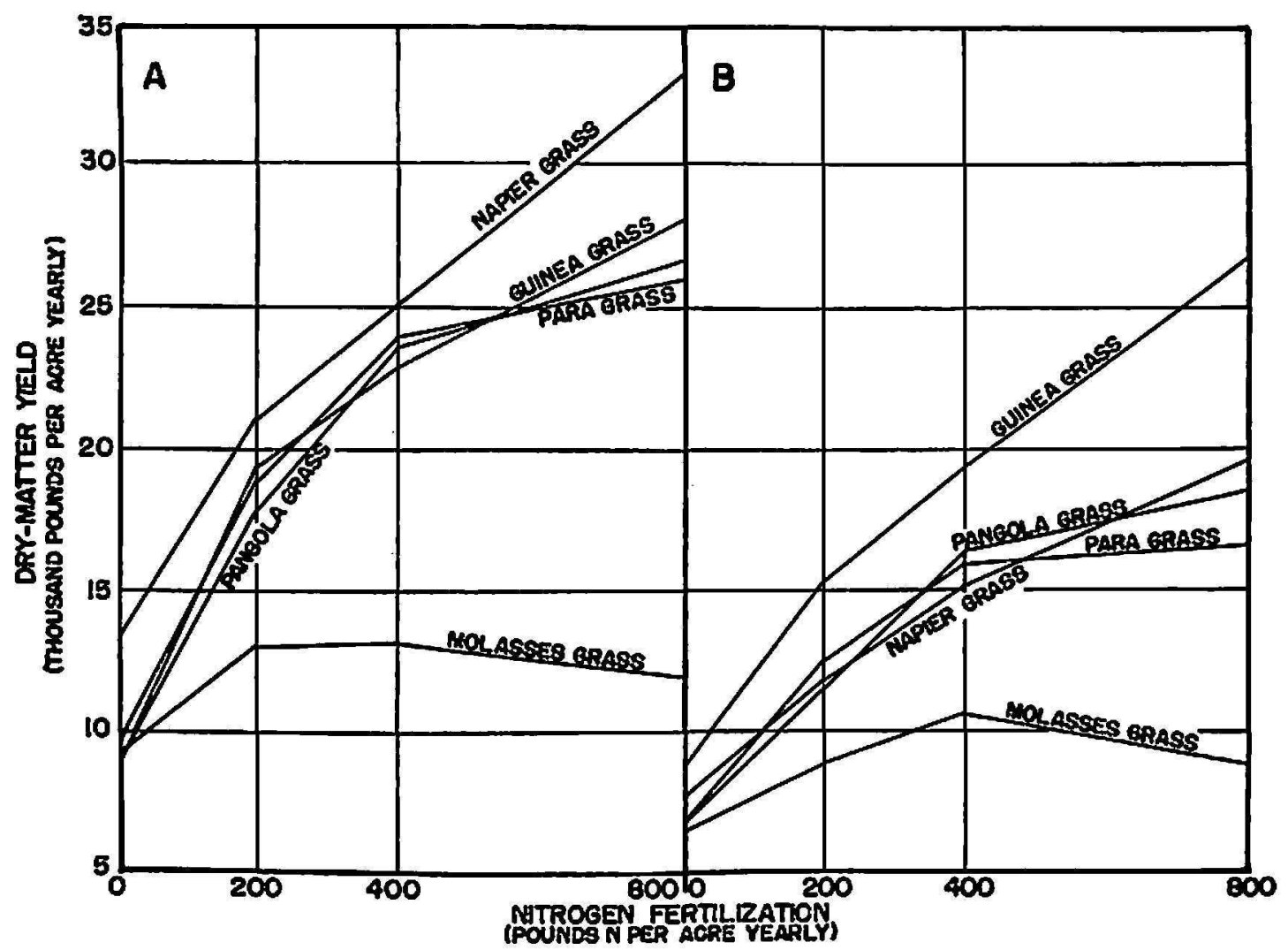

FIG. 1.-The effects of nitrogen fertilization on yields of 5 grasses in the humid mountains of Puerto Rico when cut every 60 days (A) and grazed every 40 days (B).

sponded only to the 200-pound rate of nitrogen at all seasons. The other grasses generally responded well to the 200-pound level during the winter months of slow growth, while responding strongly to at least the 400pound level during the remainder of the year.

It is important to note in figure 4 that the superiority in yields of Guinea grass with grazing management was attained during seasons of fast growth. There was no great difference in the productivity of Napier, Guinea, Para, and Pangola grasses during seasons of slow growth when forage is at a premium.

Little or no weeding was required with heavy nitrogen applications, but weeds were a constant problem in the no-nitrogen plots. 


\section{PROTEIN CONTENTS AND YIELDS}

Table 1 shows that all the grasses had a remarkably similar protein content when treated alike. For example, with cutting management and 400

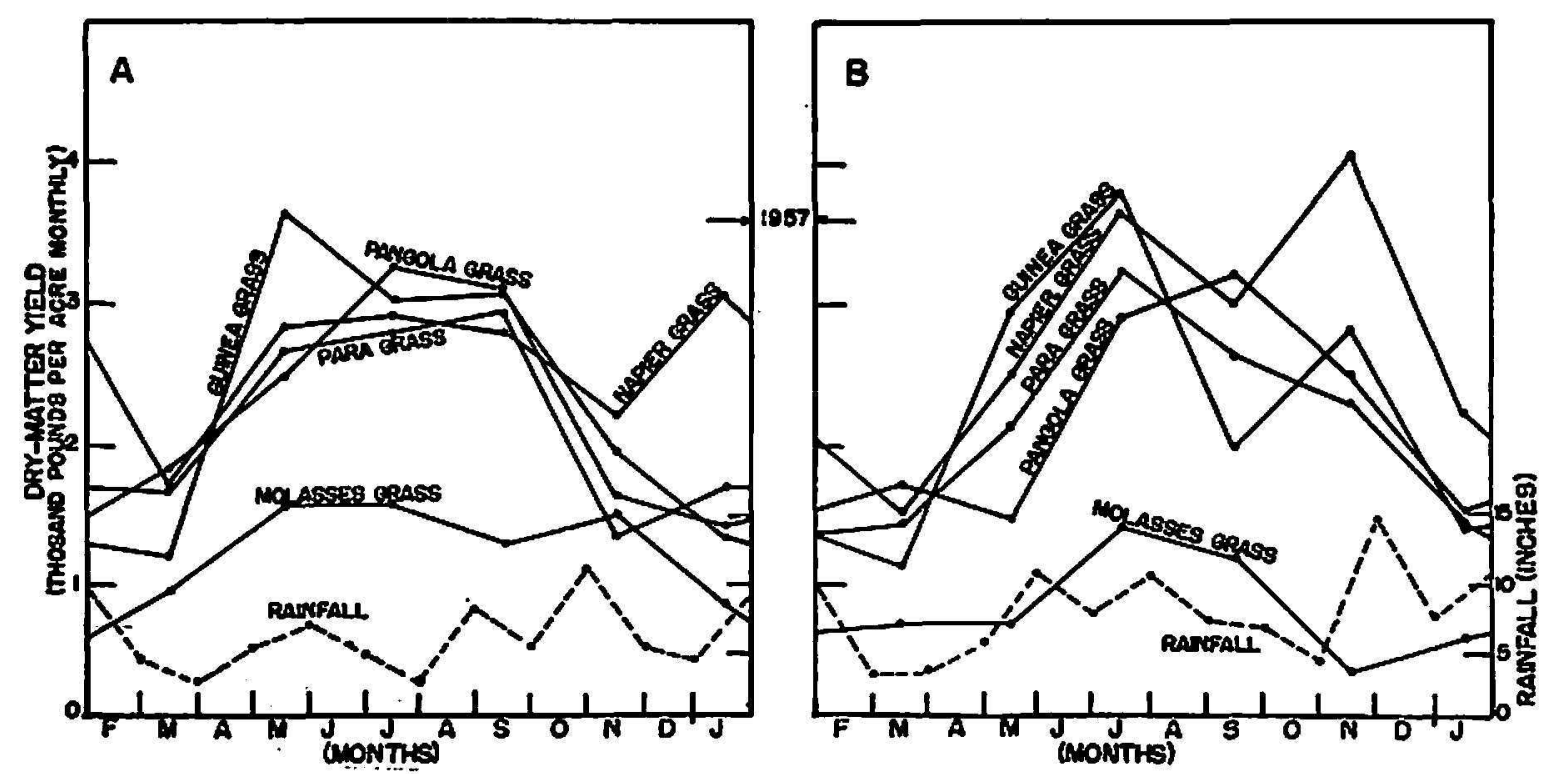

Fig. 2.-The seasonal productivity in 1956 (A) and 1958 (B) of heavily fertilized grasses cut every 60 days over a 2-year period in the humid mountain region of Puerto Rico.

TABLE 2.-The effect of nitrogen rates (pounds) on seasonal variations in yields of 5 grasses expressed as percentage by which winter yields were lower than yields during the remainder of the year

\begin{tabular}{l|c|c|c}
\hline \multirow{2}{*}{ Grass } & \multicolumn{3}{|c}{ Effect of indicated pounds N per acre yearly } \\
\cline { 2 - 4 } & 0 & 200 & 400 \\
\hline Para & 0 & 26 & 35 \\
Guinea & 19 & 42 & 50 \\
Napier & 23 & 23 & 31 \\
Pangola & 0 & 31 & 40 \\
Molasses & 21 & 30 & 29 \\
\hline \multicolumn{1}{r|}{ Average } & 12.6 & 30.4 & 37 \\
\hline
\end{tabular}

pounds of nitrogen per acre yearly, the protein contents of Para, Guinea, Napier, and Pangola grasses varied only from 7.5 to 8.0 percent. The slightly higher protein content of molasses grass is attributed to the concentrating effect of lower yields in the presence of an equal supply of nitrogen.

Protein content of all grasses increased with nitrogen rates, with the 
highest increases occurring beyond the 200-pound level. With cutting management, protein content increased from an average of 7 percent when no nitrogen was applied to 10.1 percent when 800 pounds of nitrogen were applied.

Protein content of the forage was considerably higher when the grasses were harvested by simulated grazing, largely due to the shorter harvest nterval used.

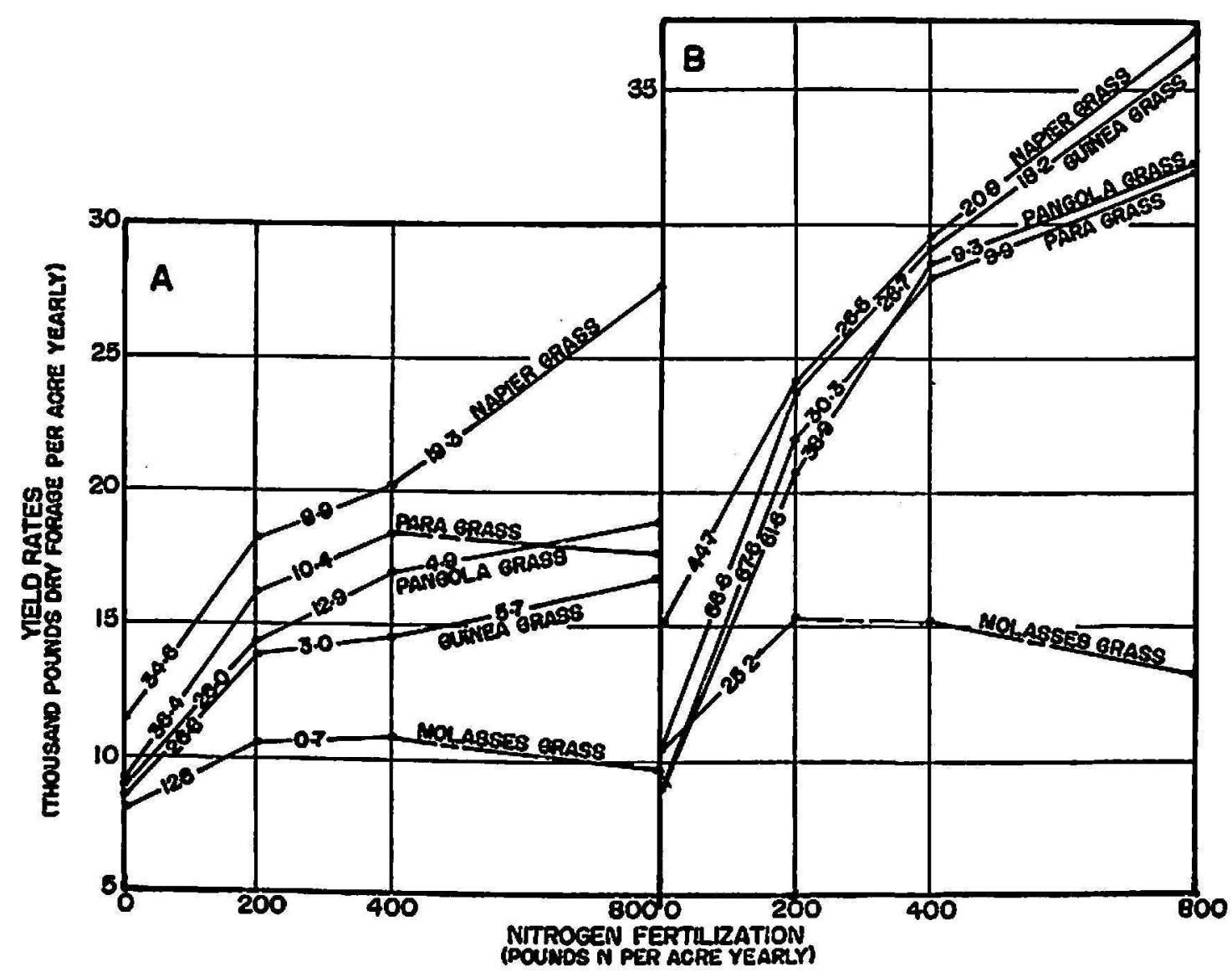

FrG. 3.-The responses of 5 grasses to nitrogen fertilization during seasons of slowapproximately December through March (A), and fast-remainder of the year (B), growth when harvested by cutting every 60 days. Numbers show pounds of dry forage per pound increment of $N$.

Season of the year had a marked and very similar influence on the protein content of all grasses, with highest contents occurring when yields were lowest during the winter months and vice versa. With cutting management and 800 pounds of nitrogen, for example, protein content of the grasses varied from as low as 6.9 to as high as $\mathbf{1 5 . 6}$ percent.

\section{EFFICIENCY OF NITROGEN UTILIZATION}

Table 1 shows that lowest recovery of fertilizer nitrogen in the forage was with molasses grass, with Napier grass recovering less nitrogen than the 
others at the lower rates. Recovery of nitrogen tended to be lower when the grasses were harvested by simulated grazing and to decrease slightly with increasing nitrogen rates. At the 400 -pound rate of nitrogen an average of about 40 percent of the fertilizer nitrogen was recovered in the forage.

There were no marked over-all differences in the pounds of forage pro-

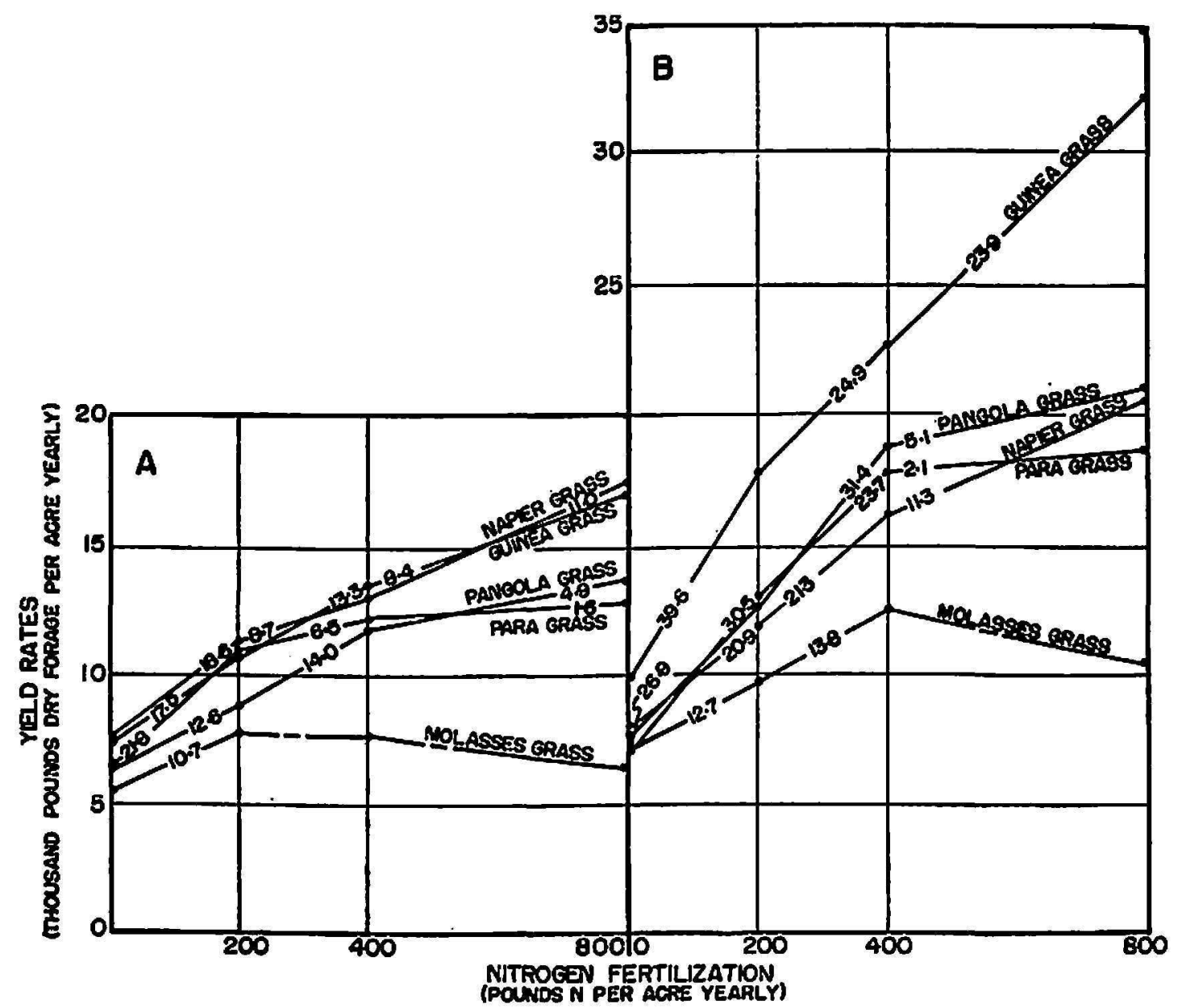

Fig. 4.-The responses of 5 grasses to nitrogen fertilization during seasons of slowapproximately December through March (A), and fast-remainder of the year (B), growth with grazing management. Numbers show pounds of dry forage per pound increment of $\mathrm{N}$.

duced per pound of nitrogen by the highest yielding grasses at rates of 400 pounds or less per acre (table 1). Molasses grass produced much less forage per pound of nitrogen at all rates than did the other grasses. With all grasses, forage produced per pound of nitrogen decreased rapidly with increasing nitrogen rates. Para grass, for example, produced 54.5, 21.9, and 5.1 pounds of forage per pound of nitrogen at the $200-, 400-$, and 800-pound rates, respectively. Less forage was generally produced per pound of nitrogen with grazing than with cutting management.

Season of the year markedly affected the efficiency of nitrogen utilization 
as shown in figures 3 and 4, with more dry matter produced per pound of fertilizer nitrogen during seasons of fast growth. For example, with cutting management, the second 200 pounds of nitrogen with the four highest yielding grasses produced an average of only 8.8 pounds of forage per pound of nitrogen in winter, compared with 30.8 pounds during the remaining 8 months of the year.

\section{FORAGE COMPOSITION}

Dry-matter content of the grasses, except Napier which had only about 19 percent, varied between 23 and 27 percent.

Table 3 shows the composition of the various grasses when fertilized with

TABLE 3.-The mineral composition and lignin content of 5 tropical grasses when heavily fertilized ${ }^{1}$ and cut every 60 days $^{2}$

\begin{tabular}{l|r|r|r|r|r|r|r}
\hline \multicolumn{1}{c|}{ Grass } & Nitrogen & $\begin{array}{c}\text { Phos- } \\
\text { phorus }\end{array}$ & Potassium & Calcium & $\begin{array}{r}\text { Mag- } \\
\text { nesium }\end{array}$ & Lignin & D.L.N.2 \\
\cline { 2 - 6 } Para & 1.28 & 0.18 & 2.20 & 0.48 & $\mathbf{0 . 3 3}$ & $\mathbf{8 . 4 1}$ & 54.9 \\
Guinea & 1.25 & .19 & 2.36 & .65 & .43 & 9.43 & 54.8 \\
Napier & 1.20 & .25 & 2.78 & .38 & .25 & 8.81 & 54.4 \\
Pangola & 1.26 & .20 & 2.32 & .46 & .28 & 8.91 & 54.4 \\
Molasses & 1.57 & .24 & 2.24 & .43 & .33 & 9.81 & 55.7 \\
\hline
\end{tabular}

$1400 \mathrm{lb} . \mathrm{N} ; 200 \mathrm{lb} . \mathrm{P}_{2} \mathrm{O}_{5} ;$ and $400 \mathrm{lb}$. $\mathrm{K}_{2} \mathrm{O}$ per acre yearly in 6 equal applications.

${ }^{2}$ All values are in percentages on a dry-weight basis and are averages of 4 replicate samples composited yearly from all cuttings.

3 Digestible laboratory nutrients determined by the method of Thurman and Wehunt $(5)$.

400 pounds of nitrogen per acre yearly and harvested by cutting every 60 days. Guinea grass had a markedly higher calcium and magnesium content than the others. Otherwise, the grasses were similar in mineral and lignin content and in "digestible nutrients" (D.L.N.).

\section{DISCUSSION}

The high yields of forage produced on this steep, eroded soil are worthy of note. Yields and responses of the grasses to nitrogen are very similar to those on the north coast (8). With cutting management and 400 pounds of nitrogen, all grasses, except molasses, yielded about 24,000 pounds of dry matter, or 50 to 60 tons of green forage, per acre yearly, containing about 8 percent of protein. This is enough to feed about five steers per acre. With simulated grazing management and $\mathbf{4 0 0}$ pounds of nitrogen, Guinea grass yielded about 19,000 pounds of dry matter per acre yearly, compared to about 15,000 pounds for Pangola, Para, and Napier grasses. It is interest- 
ing to note that in a nearby grazing experiment, well-fertilized Guinea grass pastures produced about 1,200 pounds gain-in-weight per acre yearly when grazed by young dairy heifers, compared to about 950 pounds produced by Pangola and Napier grass pastures. ${ }^{4}$

The lower yields obtained with grazing compared to cutting management, can be explained by the shorter harvest interval ( 8 ) as well as by trampling losses. Guinea grass was probably least affected by shortening the harvest interval since Vicente, et al. (8), found that yields of Napier were reduced about 45 percent, those of Para about 23 percent, but those of Guinea grass only 16 percent, when the harvest interval was shortened from 60 to 40 days. The approximately 8 inches of growth left on the ground also favored Guinea and molasses grasses over the others. ${ }^{4}$

The similarity in yields, protein content, response to nitrogen fertilization and seasonal growth rates by Napier, Para, Pangola, and Guinea grasses under these conditions is striking. Although molasses grass clearly yields less than the others, the difference was accentuated in this experiment by its sensitivity to cutting and to burning by fertilizer, which reduced its stand appreciably.

The slow growth during winter was frequently associated with low rainfall, but yields were also low during this period even when rainfall was abundant, as occurred in January of 1956 and 1958. On the other hand, the low rainfall in June and July of 1956 did not affect yields. Apparently, the shorter days and cooler weather of winter reduce growth and stimulate early flowering of these grasses.

Nitrogen fertilization accentuated seasonal variations in yield by increasing growth only moderately during winter, while stimulating it tremendously during the remainder of the year.

Assuming that 15 pounds or more of dry forage must be produced per pound of fertilizer nitrogen, it appears from table 1 that with both systems of management, the application of 400 pounds of nitrogen per acre yearly to all grasses except molasses, was warranted. However, figure 3 shows that only the 200-pound rate was warranted during the winter months of slow growth, while it paid to apply at least 400 pounds of nitrogen to these four grasses during the remainder of the year.

By using the 200-pound rate in winter and the 400-pound rate during the remaining months, only about 330 pounds of nitrogen would be used yearly, yet, annual yields would be similar to those obtained with the 400 pound rate, as shown in table 4. However, these data show that such a practice further accentuates seasonal variations in yield and would be desirable only when the number of animals can be seasonally adjusted, or

'Authors' unpublished data. 
where forage can be stored as hay or silage, which is usually impractical on the steep slopes of the humid mountain region.

On the other hand, these data show that seasonal variations can be greatly decreased by using the 400-pound rate of nitrogen to obtain maximum yields during the four critical winter months and the 200-pound rate to reduce summer growth. With such a system, only about 265 pounds of nitrogen are used per acre yearly, and an additional 50 pounds or so may be saved by counting on residual effects of the heavy winter applications (8) and not fertilizing early in spring. Yet, total yields are cut only about

TABLE 4.-The approximale effect of $\$$ systems of nitrogen fertilization on yields and seasonal variations in growth of 5 grasses cut every 60 days

\begin{tabular}{|c|c|c|c|c|c|c|}
\hline \multirow{2}{*}{ Grass } & \multicolumn{3}{|c|}{$\begin{array}{l}\text { Yields in pounds of dry forage } \\
\text { per acre yearly }\end{array}$} & \multicolumn{3}{|c|}{$\begin{array}{l}\text { Seasonal variations in yield as } \\
\text { percentage of winter yields } \\
\text { lower than summer }\end{array}$} \\
\hline & $A^{1}$ & $\mathbf{B}^{2}$ & $C^{2}$ & $A^{2}$ & $\mathrm{~B}^{2}$ & $C^{a}$ \\
\hline Para & 24,000 & 24,200 & 20,800 & 35 & 46 & 17 \\
\hline Guinea & 23,000 & 24,100 & 20,800 & 50 & 52 & 39 \\
\hline Napier & 25,200 & 24,400 & 22,500 & 31 & 37 & 15 \\
\hline Pangola & 23,700 & 23,900 & 19,500 & 40 & 50 & 18 \\
\hline Molasses & 13,300 & 13,600 & 13,700 & 29 & 28 & 29 \\
\hline Average & 21,850 & 22,040 & 19,460 & 37 & 42.6 & 23.6 \\
\hline
\end{tabular}

${ }^{1} \mathrm{~A}, 400 \mathrm{lb}$. $\mathrm{N}$ per acre yearly in 6 equal applications.

${ }^{2} \mathrm{~B}, 300 \mathrm{lb}$. $\mathrm{N}$ in 2 winter applications at the 200 -lb. rate, and 4 summer applications at the $400-\mathrm{lb}$ rate.

${ }^{3} \mathrm{C}, 265 \mathrm{lb} . \mathrm{N}$ in 2 winter applications at the $400-\mathrm{lb}$. rate and 4 summer applications at the $200-1 b$. rate.

20 percent, and this occurs during the season when forage is abundant. About 20,000 pounds of dry matter would be produced per acre yearly with this system by all grasses, except molasses.

Seasonal variations in yield could be further reduced by using a longer harvest interval to increase yields in winter and a shorter one to reduce summer yields (8). Such a practice would also reduce seasonal variations in protein content since the depressive effect of the longer harvest intervals in winter would be counteracted by the heavier nitrogen applications, while the shorter harvest interval in summer would help to compensate for the lower nitrogen rates.

Several variations in yield could also be induced by grazing in summer while using a lower nitrogen rate and cutting in winter while using a higher nitrogen rate. 
The higher protein content of the grasses during seasons of slow growth, the slightly higher protein content of the lower yielding molasses grass, and the higher protein content with grazing management, are explained by the concentrating effect of lower yields in the presence of a relatively constant amount of nitrogen in the soil.

\section{SUMMARY}

The productivity of Napier, Guinea, Para, Pangola, and molasses grasses, as affected by nitrogen fertilization and season of the year under both cutting and simulated grazing management, were determined under conditions typical of the humid mountain region of Puerto Rico.

Molasses grass yielded much less than the others, all of which were very similar in yield, response to nitrogen fertilization, and seasonal growth rates with both harvest procedures, except that Guinea grass outyielded the others with grazing management. With cutting management and 400 pounds of nitrogen per acre yearly, Napier, Guinea, Para, and Pangola grasses yielded about 24,000 pounds of dry matter per acre yearly having about 8 percent of protein. Yields were lower with grazing than with cutting management.

Season of the year markedly affected growth of all grasses with lowest yields occurring from December through March. Seasonal variations were accentuated by nitrogen fertilization.

Annual yields of the Para, Guinea, Napier, and Pangola grasses increased rapidly with nitrogen rates up to 400 pounds. However, response was generally limited to the 200-pound rate during seasons of slow growth, but was strong up to at least the 400-pound rate at other times. Molasses grass responded only to the application of 200 pounds of nitrogen per acre yearly at all seasons.

Protein content of all the grasses was similar, increased with nitrogen rates, was higher during seasons of slow growth, and lower with cutting than with simulated grazing management. Napier grass had the lowest drymatter content, while Guinea grass had a markedly higher calcium and magnesium content than the others. Otherwise, the forages were very similar in mineral and lignin content.

There was little difference in efficiency of nitrogen utilization by the highest yielding grasses. Efficiency was lower with grazing management, higher during seasons of fast growth, and decreased with increasing nitrogen rates.

\section{RESUMEN}

Se estudió la productividad de las yerbas Napier, Guinea, Pará, Pangola y Melao, con distintos niveles de nitrógeno, durante distintas' épocas del 
año, cosechándose por corte y pastoreo simulado bajo condiciones típicas de la región montañosa de Puerto Rico.

La yerba Melao tuvo un rendimiento menor que las otras, las cuales tuvieron una producción similar y respondieron al nitrógeno en forma similar. La yerba Guinea produjo más que las otras en pastoreo simulado. Cuando se cosecharon por corte y se les aplicó 400 libras de nitrógeno por cuerda anualmente, las yerbas Napier, Guinea, Pará, y Pangola produjeron alrededor de 24,000 libras de forraje seco por cuerda por año, con un 8 por ciento de proteína. Las yerbas produjeron menos cuando se cosecharon simulando el pastoreo que cuando se cortaban.

La época del año afectó el crecimiento de las yerbas, las cuales produjeron los rendimientos más bajos en los meses de diciembre a marzo. Las aplicaciones de nitrógeno acentuaron la variación en el crecimiento durante las distintas épocas del año.

El rendimiento de las yerbas Pará, Guinea, Napier y Pangola aumentó rápidamente según se aumentaban los niveles de nitrógeno, por lo menos hasta 400 libras de nitrógeno por cuerda por año. Este aumento fué más notable durante las épocas de crecimiento rápido. La yerba Melao respondió sólo a la aplicación de 200 libras de nitrógeno por cuerda por año.

El contenido de proteína de todas las yerbas fué similar. El contenido de proteína aumentó según aumentaba el nivel de nitrógeno; subió durante épocas de crecimiento lento, y bajó durante épocas de crecimiento rápido; y fué más bajo cuando se cortaba la yerba que cuando se simuló el pastoreo. La yerba Napier tuvo el contenido más bajo de materia seca y la Guinea el más alto de calcio y magnesio.

Las cuatro yerbas de producción más alta difirieron poco en su eficiencia para utilizar el nitrógeno. La eficiencia de utilización de este nutriente fué menor bajo el pastoreo simulado, subió durante la época de crecimiento rápido y bajó según aumentaba el nivel de nitrógeno.

\section{LITERATURE CITED}

1. Abruña, F., Pearson, R. W., and Elkins, C., Quantitative evaluation of soil reaction and base status changes resulting from field applications of residual acid nitrogen fertilizer, paper presented at the Annual Meeting of the Soil Sci. Soc. Amer. Proc. 22 (6) 539-42, Nov.-Dec. 1958.

2. Little, S., Vicente-Chandler, J., and Abruña, F., Yield and protein content of irrigated Napier grass, Guinea grass, and Pangola grass, as affected by nitrogen fertilization, Agron. J. 51(2) 111-3, 1959.

3. Rivera-Brenes, L., Technical and Economic Aspects of Roughage Production in Puerto Rico, Tech. Paper No. 2, Agr. Exp. Sta., Univ. P. R., 1953.

4. Rodriguez, J. P., Effect of nitrogen applications on the yields and composition of forage crops, J. Agr. Univ. P.R. 33(3) 98-117, 1949.

5. Thurman, R. L., and Wehunt, E. J., A laboratory method for determining digestible nutrients, Agron. J. 47(7) 302-3, 1955. 
6. Vicente-Chandler, J., Rivera-Brenes, L., Caro-Costas, R. R., Rodriguez, J. P., Boneta, E., and Gracia, W., The Management and Utilization of the Forage Crops of Puerto Rico, Agr. Exp. Sta., Univ. P. R., Bul. 116, 1953.

7. Vicente-Chandler, J., and Figarella, J., Growth characteristics of Guinea grass on the semiarid south coast of Puerto Rico and the effect of nitrogen fertilization on forage yields and protein content. J. Agr. Univ. P. R. 42(3) 151-60, 1958.

8. Vicente-Chandler, J., Silva, S., and Figarella, J., The effect of nitrogen fertilization and frequency of cutting on the yield and composition of three tropical grasses, Agron. J. 51(4) 202-6, 1959. 